\title{
The Relationship Between Service Quality and Customer Satisfaction in India's Rural Banking Sector: An Item Analysis and Factor-Specific Approach
}

\section{Mohammad Adil ${ }^{*}$}

\begin{abstract}
Earlier research has shown that, in today's highly competitive business world, service quality and satisfaction are central to management concerns for marketing effectiveness and success. This study attempts to determine customerperceived service quality at rural Indian banks and identify the most significant predictors of overall customer satisfaction based on a five-dimensional 'performance-only' scale measuring service quality. Data was collected from 289 patrons of rural banks, based on a seven-point Likert scale ranging from 1 ("strongly disagree") to 7 ("strongly agree"). The absence of a reliable sampling frame necessitated following a controlled sampling technique. In order to extract factors relevant to service quality, we employ exploratory factor analysis, means, standard deviations, $t$-tests, and regression analysis. Our preliminary analysis indicates that rural customers report high levels of perceived service quality across all five dimensions while the results of the regression analysis $(\beta)$ show that reliability and assurance explain overall customer satisfaction at rural banks in India. The study's findings can be employed by the banking industry to restructure and prioritize its service quality and develop appropriate promotional strategies by highlighting relevant aspects of service quality and customer satisfaction.
\end{abstract}

Keywords: Service quality, customer satisfaction, SERVPERF, rural, retail bank, India.

JEL classification: M10, M20, M31, M39.

\section{Introduction}

It is widely acknowledged that the Indian banking sector has contributed significantly to the country's rising gross domestic product (GDP) (Kamath, 2003), making it one of the fastest emerging economies. Over the years, the banking industry in India has matured considerably and by and large proved resilient (Subbarao, 2010). The banking index has

\footnotetext{
* The author is a research scholar at the Faculty of Management Studies and Research at Aligarh Muslim University in India. He can be contacted at adilcms07@gmail.com.
} 
shown a compounded annual growth rate of over 51 percent since April 2001, accounting for over 7.7 percent of GDP with over INR 7,500 billion in market capitalization (McKinsey \& Company, 2010). However, to improve business performance, banks have long attempted to address the issue of service quality (Yavas, Bilgin, \& Shemwell, 1997).

Service quality and customer satisfaction are critical for marketers and consumer researchers because of their positive impact on customer retention and firm profitability (Caru \& Cugini, 1999; Fournier \& Mick, 1999; Anderson \& Mittal, 2000; Meuter, Ostrom, Roundtree, \& Bitner, 2000; Adil, 2012; Adil \& Khan, 2012). The literature shows that service quality and satisfaction are central to management concerns for marketing effectiveness and success. In fact, they have become a corporate goal as an increasing number of organizations attempt to improve their level of service quality to enhance customer satisfaction. From customers' perspective, service quality significantly influences their satisfaction. It is, therefore, imperative on the part of banks to stress on both service quality and customer satisfaction to expand their customer base and profitability.

The customer satisfaction paradigm posits that confirmed standards lead to moderate satisfaction, positively disconfirmed (exceeded) standards lead to high satisfaction, and negatively disconfirmed (underachieved) standards lead to dissatisfaction (Al-Eisa \& Alhemoud, 2009). The distinction and association between service quality and customer satisfaction is continuously debated in marketing literature (Spreng \& Mackoy, 1996). Although the research acknowledges a strong positive correlation between these two variables (Yavas et al., 1997), there is substantial debate on the nature of their causal relationship (see, for example, Parasuraman, Zeithaml, \& Berry, 1988; Bitner, Booms, \& Tetreault, 1990; Bolton \& Drew, 1991). Some studies argue that service quality is an outcome of customer satisfaction, while other, more recent studies argue the opposite. Since the bulk of the research supports the latter concept (Jamal \& Naser, 2002; Ijaz, Irfan, Shahbaz, Awan, \& Sabir, 2011; Adil, 2012), we treat service quality as an antecedent of satisfaction.

Few empirical studies focus on service quality and customer satisfaction at Indian rural retail banks. The existing literature looks primarily at the service quality attributes important for urban consumers. Thus, there is a pressing need to bridge this gap by carrying out studies encompassing rural consumers, especially in the case of emerging economies such as India. In order to bridge this gap, we assess the contribution of five aspects of service quality in explaining overall 
customer satisfaction at Indian rural banks. We also explore the varying importance attached to these five dimensions by rural consumers. To better allocate limited resources, it is pertinent as well as beneficial to identify the differences among these dimensions so that rural banks can focus on the most important dimensions that significantly predict overall satisfaction.

\section{Literature Review}

\subsection{Perceived Service Quality}

As a high-involvement industry, banking requires the delivery of excellent services and products to its customers, which is essential for banks to differentiate themselves from their competitors (Arasli, Turan Katrircioglu, \& Mehtap-Smadi, 2005). Several studies (Aldlaigan \& Buttle, 2002; Narang, 2010) assert that individual perception is the most important determinant of consumer value perception. These value perceptions thus formulated tend to impact customer satisfaction and the future purchase intentions of consumers (Bolton \& Drew; 1991). To better understand service quality, various studies have conceived it differently. Parasuraman et al. (1988), for example, regard service quality as global judgment or attitude relating to the superiority of the service, while Bitner et al. (1990) refer to it as a customer's overall impression of the relative inferiority/superiority of an organization and its services.

Asubonteng, McCleary, and Swan (1996) conceptualize service quality as the difference between a customer's expectations of service performance prior to the service encounter and their perception of the service received. Ziethaml (1998) defines it as a consumer's assessment of service quality by employing both interior and exterior attributes of lowlevel production quality or service quality. While there are numerous marketing-related studies on service quality, there is, however, a lack of consensus among researchers on an exhaustive and broader definition, which is a cause of major concern.

\subsection{Measures and Dimensions of Service Quality}

Over the last two decades, the most commonly used scale of service quality has been SERVQUAL (Parasuraman et al., 1988). However, researchers such as Cronin and Taylor (1992) have questioned its conceptual foundation, criticized it as being confusing, and suggested that the performance component alone be used. They recommend a performance-only service quality scale, i.e., SERVPERF. Other studies 
(Boulding, Kalra, Staelin, \& Zeithaml, 1993; Jain \& Gupta, 2004; Adil \& Khan, 2012) provide considerable support in favor of the SERVPERF scale. Though lagging behind the SERVQUAL scale in application, researchers have increasingly started using the performance-only measure of service quality (Cronin \& Taylor, 1992; Boulding et al., 1993; Adil \& Khan, 2011; Khan \& Adil, 2011; Adil, 2012).

\subsection{Measures and Dimensions of Customer Satisfaction}

The measurement of customer satisfaction has grown dramatically, with more than 15,000 scholarly articles and business reports published in the last two decades (Walker, Smither, \& Waldman, 2008). During this period, many researchers have attempted to develop theoretical and methodological frameworks to measure customer satisfaction in a more reliable fashion (see Meng, Tepanon, \& Uysal, 2008). A common feature of their underlying methodologies is a heavy reliance on a single-item approach to measuring customer satisfaction (see Smith \& Bolton, 2002). Hansen and Hennig-Thurau (1999), in their comparative investigation of national customer satisfaction indices, say that, "on the single-item scale used, the difference between the best and the worst satisfaction score on the level of branches is approximately only 0.2 points that implies the assumption that the used measurement scale has no good selectivity due to skewness."

The issue of single-item versus multiple-item measures has long been the subject of debate among methodologists in the social sciences in general and in the field of marketing in particular. Advocates of single-item measures argue that such measures allow for more efficient use of questionnaire space, reducing the cost of survey development and dataprocessing, enhancing face validity, and identifying longitudinal changes in constructs under study (see Bergkvist \& Rossiter, 2007). Conversely, opponents of the single-item approach (see Shin \& Elliott, 2001; Soderlund \& Ohman, 2003) argue that such an approach is too simplistic in that it fails to capture all the salient dimensions of an examined construct, and simultaneously precludes the calculation of the internal reliability of that construct (Soderlund \& Ohman, 2003). Despite this continuous debate, customer satisfaction, in more recent studies, is still measured using the single-item approach (Brochado, 2009; Ladhari, 2009). 


\subsection{Customer Satisfaction}

Customer satisfaction is the judgment that emerges out of comparing pre-purchase expectations with the post-purchase evaluation of a product or service experience (Oliver, 1980). Customer satisfaction is identified as a salient precursor to customer loyalty, retention, behavioral intention, market share, and profitability (see, for example, Taylor \& Baker, 1994; Muffato \& Panizzolo, 1995; Levesque \& McDougall, 1996; Heskett, Sasser, \& Schlesinger, 1997; Fournier \& Mick, 1999; Anderson \& Mittal, 2000; Athanassopoulos, Gournaris, \& Stathakopoulos, 2001; Jamal \& Naser, 2002; Beerli, Martin, \& Quintana, 2004; Olorunniwo, Hsu, \& Udo, 2006; Wood, 2008). Thus, customer satisfaction is widely recognized as a key driver of the formation of consumers' future purchase intentions (Taylor \& Baker, 1994) and the likelihood of their patronizing a firm in the future (Kotler \& Amstrong, 2006).

Other empirical studies identify service quality, price, convenience, and innovation as key drivers of customer satisfaction (see Athanassopoulos, 2000). The prevalence of such research has heightened the interest of many retail banks in India in measuring the level of their customers' overall satisfaction with the products and services offered (Mishra, 2009). Measuring customer satisfaction has great potential to provide retail bank managers with information about their actual performance and the expectations of their customers. Such information allows them managers to fine-tune their efforts to improve the quality of their services or to deliver services that appear attractive to customers (Shin \& Elliott, 2001). In this manner, measuring customer satisfaction is expected to enhance the bank's reputation and image, increase attention to customer needs, and reduce customer attrition (Muffato \& Panizzolo, 1995), ultimately increasing profitability. Thus, for a service provider, customer satisfaction is not an ultimate goal in itself, rather, it is a means of yielding greater profits.

\subsection{Relationship between Service Quality and Customer Satisfaction}

The relationship between service quality and satisfaction remains an important issue in the services marketing literature (Jamal \& Naser, 2002), specifically in the field of banking (Avkiran, 1994). Service quality is an important tool for measuring customer satisfaction (Pitt, Watson, \& Kavan, 1995) and a prerequisite for establishing a satisfactory relationship with customers. As service quality improves, the probability of customer satisfaction increases. Increased customer satisfaction thus leads to behavioral outcomes such as commitment, customer retention, the creation 
of a mutually rewarding relationship, increased customer tolerance, and positive word-of-mouth (Reichheld, 1996; Moutinho \& Goode, 1995; Heskett et al., 1997; Newman, 2001). Cronin and Taylor (1992), Aldlaigan and Buttle (2002), Sureshchandar, Rajendran, and Anantharaman (2002, 2003), Bei and Chiao (2006), and Adil (2012) all report that service quality has a positive effect on satisfaction.

\section{Research Methodology}

\subsection{Objectives and Hypotheses Formulation}

The study's objective's are:

- To determine customer-perceived service quality at Indian rural banks.

- To identify which dimensions of service quality contribute significantly to measuring overall satisfaction in the context of Indian rural banks.

- To explore the applicability and efficacy of the original SERVPERF scale in measuring perceived service quality at rural retail banks in India.

Based on the literature and the objectives above, we formulate and test the following hypotheses:

- H1: There are no significant differences in the perceptions of rural customers in terms of tangibles, reliability, assurance, responsiveness, and empathy as dimensions of service quality.

- H2: Service quality has a positive significant impact on customer satisfaction.

\subsection{Development of Instrument}

A number of empirical studies have relied on the SERVPERF model in surveys of service industries such as car retailing, hospitality, banking, restaurants, medical services, travel and tourism, etc. (see Mazis, Ahtola, \& Klippel, 1975; Churchill \& Surprenant, 1982; Bolton \& Drew, 1988, 1991; Woodruff, Cadotte, \& Jenkins, 1983; Angur, Nataraajan, \& Jaheera, 1999; Jain \& Gupta, 2004; Kumar \& Gulati, 2010; Adil, 2011a; Adil, 2011b; Adil, 2012). In line with their observations, we use the SERVPERF-measuring instrument developed by Cronin and Taylor (1992). We therefore measure banks' service quality using 22 items based on an expanded list of five dimensions: (i) tangibles (four items), (ii) reliability (five items), (iii) responsiveness (four items), (iv) assurance (four items), and (v) empathy (five items), while customer satisfaction is measured with a single item. 
The research instrument consists of a structured questionnaire, on which respondents were required to indicate their level of involvement with the help of a seven-point Likert scale where $1=$ "strongly disagree" and $7=$ "strongly agree". The seven-point Likert scale was employed so that our findings could be compared with those of previous studies that had also relied on the use of this measurement tool (Adil \& Khan, 2011; Khan \& Adil, 2011). The research instrument consisted of two categories of questions. The first set of questions related to demographics and the second set dealt with various items of the standard SERVPERF scale also used also by previous studies (see Jain \& Gupta, 2004; Vanniarajan \& Anbazhagan, 2007; Vanniarajan \& Nainamohamed, 2008; Selvaraj, 2009; Kumar \& Gulati, 2010; Adil, 2011a, Adil, 2012) to measure bank service quality in India.

Initially, the research instrument was developed in English and given independently to three subject experts to obtain feedback on its content, layout, wording, and the ease with which the measurement items could be understood. In general, the comments were positive with some suggestions that were taken into account when revising the questionnaire to ensure content validity. The English version of the research instrument was later translated into Hindi, which is commonly spoken in western Uttar Pradesh (where the respondents were located). As an additional precaution, the Hindi version was first pretested on a representative sample of ten customers of rural banks, and further tested for originality by 'back-translation' (see McGorry, 2000).

\subsection{Sampling Plan}

The study's population of interest comprised all the villages in India, but keeping in mind practical considerations such as the penetration of retail banks and proximity, it was decided to select the district of Aligarh, which comprises 12 blocks and a total rural population of 2,457,268 individuals (India, Ministry of Home Affairs, 2011). Due care was taken while administering the questionnaire in order to prevent bias from the point of view of any particular demographic group or particular bank. Respondents were approached at different banks with the objective of generating a representative sample and minimizing bias, owing to the proximity of Aligarh's urban center.

For survey research, probability sampling is preferred to nonprobability sampling (Saunders, Thornhill, \& Lewis, 2000). According to Trochim (2006), however, there may be circumstances, as in this case, 
where it is not feasible or practical to undertake probability sampling, especially in situations where a reliable sample frame does not exist. Here, too, the lack of a reliable sampling frame made it necessary to adopt a nonprobability-based purposive sampling procedure (see Patsiotis, Hughes, \& Webber, 2012).

\subsection{Data Collection}

The data for this study was collected over August-November 2011 on a one-to-one basis from "willing respondents". ${ }^{1}$ The Hindi version of the questionnaire was personally administered to roughly 330 respondents with bank accounts in designated rural bank branches located around Aligarh city. Illiterate respondents were personally helped to complete the questionnaire after its contents and purpose were explained to them. In all, 307 completed questionnaires were returned; of these, 289 responses were found suitable for further analysis, giving a high response rate of 87.6 percent. The remaining questionnaires were discarded since they were incomplete in various respects.

The demographic profile of the respondents is as follows. Of a total sample size of 289 participants, the majority (179) were male (61.9 percent). A total of 131 (45.3 percent) were between the ages of 20 and 25. Most respondents were single (73.4 percent). Almost 39 percent were students, 21 percent belonged to the business class, and about 29 percent were farmers.

\section{Analysis and Discussion}

\subsection{Data Preparation}

The data was cleaned before proceeding with the final analysis. Coleby and Duffy (2005) posit that "outliers" should be reduced with the help of box plots, which graphically summarize much of the numerical data, including the median, inter-quartile range, outliers, maximum, and minimum. The inter-quartile range shows where the bulk of the data lies as well as the dispersion of the data (Brochado, 2009). Thus, outliers are detected with the help of box plots using SPSS (see Field, 2009). Figure 1 shows the box plots for each of the five dimensions of service quality and customer satisfaction.

\footnotetext{
${ }^{1}$ A "willing respondent" is defined as a rural bank customer who owns an account in a designated rural bank, maintains and operates it him/herself, and is voluntarily ready to undertake the survey.
} 


\section{Figure 1: Results of box plot}

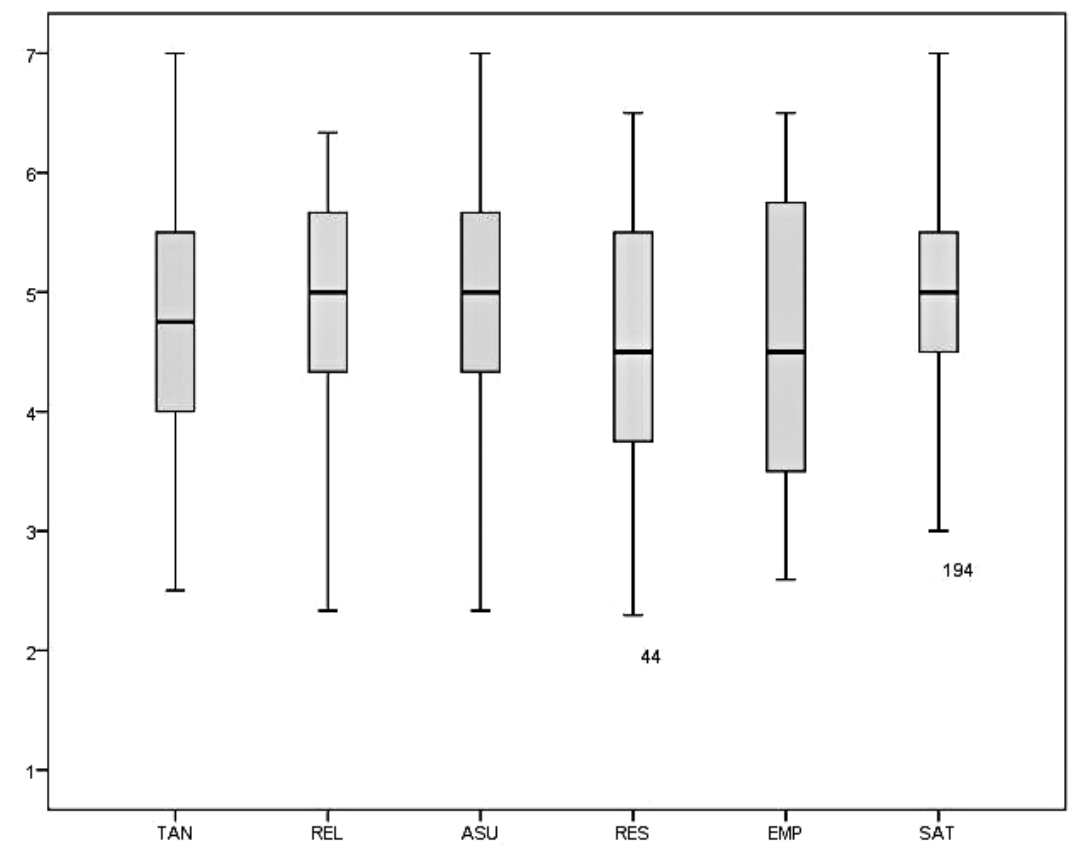

Note: $\mathrm{TAN}=$ tangibles, $\mathrm{REL}=$ reliability, $\mathrm{ASU}=$ assurance, $\mathrm{RES}=$ responsiveness, $\mathrm{EMP}=$ empathy, SAT = customer satisfaction.

Source: Author's calculations.

To test another problem with the data, i.e., that of multicollinearity, we calculate the variance inflation factor (VIF), which can be summarized as:

$$
V I F(j)=1 /\left(1-R(j)^{\wedge} 2\right)
$$

where $R(j)$ is the multiple correlation coefficient between variable $j$ and the other independent variables.

The VIF values for all the dimensions of service quality are shown in Table 1. A VIF value greater than 2 is usually considered problematic (Field, 2009). However, in the present case, all the VIF values are less than 2 , ranging between 1.007 and 1.500 . Thus, the data can be assumed to be free of the problem of multicollinearity. 


\subsection{Dimensional Analysis}

We assume that customers can distinguish between the five dimensions of service quality and attach varying importance to each, as shown in Table 1.

Table 1: Perceptions of dimensions of service quality

\begin{tabular}{lcccc}
\hline Dimension & Rank & Mean & SD & VIF \\
\hline Tangibles & 3 & 4.65 & 0.89 & 1.476 \\
Reliability & 1 & 4.81 & 1.10 & 1.007 \\
Assurance & 2 & 4.79 & 1.03 & 1.028 \\
Responsiveness & 5 & 4.39 & 1.22 & 1.500 \\
Empathy & 4 & 4.43 & 1.38 & 1.051 \\
\hline
\end{tabular}

Source: Author's calculations.

Reliability and assurance emerge as the two most important dimensions of service quality in the context of Indian rural retail banks, with mean scores of 4.81 and 4.79 , respectively. Respondents perceive responsiveness as the least important, ranking it fifth with a mean score of 4.39. Standard deviations range from 0.89 to 1.38 , which shows that the data is compact and less scattered.

\subsection{Exploratory Factor Analysis}

We use descriptive statistical techniques to refine and validate the service quality scale. As Table 2 shows, prior to the analysis, the suitability of the entire sample was tested for factor analysis, as recommended by Karatepe, Yavas, and Babakus (2005). The KaiserMeyer-Olkin (KMO) measure of sampling adequacy is above 0.500 and the Bartlett test of sphericity is significant at $p=0.001$. The results of these tests indicate that the sample is suitable for factor analytic procedures. We conduct a factor analysis on a perception scale using the principal component method and varimax rotation. Based on Hair, Black, Babin, Anderson, and Tatham's (2006) study criterion, factors with eigenvalues greater than 1.0 and factor loadings equal to or greater than 0.50 are retained. In all, 13 items load cleanly onto the five dimensions of service quality as suggested by Cronin and Taylor (1992). Nine items are dropped altogether due to high cross-loadings, creating subconstructs or loading poorly on their respective latent variables. 
Table 2: Preliminary analysis

\begin{tabular}{|c|c|c|c|c|}
\hline Variable & Loading a & KMO & $\alpha^{b}$ & Loading $\mathrm{c}$ \\
\hline Tangibles & & 0.663 & 0.694 & \\
\hline Up-to-date equipment & 0.675 & & & 0.735 \\
\hline Neat employees & $0.386^{*}$ & & & $X^{d}$ \\
\hline Physical facilities & 0.652 & & & 0.820 \\
\hline Visual service material & 0.551 & & & 0.806 \\
\hline Reliability & & 0.500 & 0.613 & \\
\hline Services delivered at promised time & 0.643 & & & 0.803 \\
\hline Services delivered as promised & $0.671^{* *}$ & & & $x$ \\
\hline Error-free records & $0.647^{* *}$ & & & $x$ \\
\hline Service right the first time & 0.727 & & & 0.803 \\
\hline Solving customer's problem & 0.505 & & & $\mathrm{x}$ \\
\hline Assurance & & 0.500 & 0.639 & \\
\hline Trustworthy & 0.587 & & & 0.801 \\
\hline Safe transaction & 0.772 & & & 0.801 \\
\hline Courteous & $0.352^{*}$ & & & $x$ \\
\hline Knowledgeable & $0.373^{*}$ & & & $x$ \\
\hline Responsiveness & & 0.687 & 0.779 & \\
\hline Prompt service & 0.687 & & & 0.792 \\
\hline Customer request & 0.610 & & & 0.805 \\
\hline Informs in advance & 0.648 & & & 0.727 \\
\hline Willing to help & $0.457^{* *}$ & & & $x$ \\
\hline Empathy & & 0.743 & 0.693 & \\
\hline Individual attention & $0.320^{*}$ & & & $x$ \\
\hline Specific needs & 0.665 & & & 0.678 \\
\hline Personal assistance & 0.717 & & & 0.989 \\
\hline Operating hours & $0.402^{* *}$ & & & $x$ \\
\hline Best interest & 0.790 & & & 0.880 \\
\hline
\end{tabular}

Note: $\mathrm{a}=$ factor loading of all items, $\mathrm{b}=$ Cronbach's alpha coefficient, $\mathrm{c}=$ factor loading of retained items only, $\mathrm{X}=$ item dropped, ${ }^{*}=$ item deleted in first iteration, ${ }^{* *}=$ item deleted in second iteration.

Source: Author's calculations.

\subsection{Measurement of Reliability and Validity}

In line with Karatepe et al. (2005), we carry out a reliability test of the constructs using Cronbach's (1951) alpha-a model of internal consistency based on the average inter-item correlation. An alpha $(\alpha)$ score above 0.6 is generally regarded as an acceptable minimum level of 
accuracy for a construct (Hair et al., 2006). As evident from Table 2, the first factor ("tangibles") was loaded with $\alpha=0.694$. The second factor ("reliability") consisted of five variables $(\alpha=0.613)$. The third and fourth factors ("assurance" and "responsiveness") were loaded with $\alpha=0.639$ and 0.779 , respectively. The fifth factor exhibited $\alpha=0.693$, referring to the final construct, "empathy". The cumulative reliability of the fivefactor scale is $\alpha=0.732$.

The validity of a scale can be defined as the extent to which differences in observed scale scores reflect the true differences among objects on the characteristic being measured rather than systematic or random error. In this study, we assessed the content validity of the measurement instrument by asking three subject experts to examine it and provide feedback. As already discussed, changes were made in line with the suggestions.

\subsection{Overall Attitude Towards Customer Satisfaction}

Since the five dimensions of SERVPERF collectively form the components that determine the satisfaction of rural retail banks, all five dimensions were taken as predictors while customer satisfaction was taken as the criterion variable.

Linear regression was carried out to analyze the impact of the independent variables on the dependent variable. Table 3 gives the results of the regression analysis. The adjusted $\mathrm{R}^{2}$ is 0.713 , which indicates that, together, the five SERVPERF dimensions explain almost 71 percent of the variation in satisfaction. Of the five SERVPERF dimensions, all have a significant impact on satisfaction. In order of importance, these are:

1. Reliability $(\beta=0.303)$

2. Assurance $(\beta=0.281)$

3. Tangibles $(\beta=0.257)$

4. Responsiveness $(\beta=0.226)$

5. Empathy $(\beta=0.179)$ 
Table 3: Results of regression analysis

\begin{tabular}{lccccc}
\hline Variable & $\begin{array}{c}\text { Unstandardized } \\
\text { coefficients }(\boldsymbol{B})\end{array}$ & $\begin{array}{c}\text { Standard } \\
\text { error }\end{array}$ & $\begin{array}{c}\text { Standardized } \\
\text { coefficients }(\boldsymbol{\beta})\end{array}$ & t-test & Sig. \\
\hline Constant & -0.476 & 0.291 & - & -2.531 & 0.035 \\
Tangibles & 0.307 & 0.089 & 0.257 & 3.285 & 0.031 \\
Reliability & 0.318 & 0.097 & 0.303 & 3.621 & 0.001 \\
Assurance & 0.314 & 0.091 & 0.281 & 3.686 & 0.002 \\
Responsiveness & 0.287 & 0.065 & 0.226 & 3.194 & 0.002 \\
Empathy & 0.189 & 0.062 & 0.179 & 2.280 & 0.029 \\
\hline
\end{tabular}

Notes: Dependent variable: customer satisfaction. Adjusted $\mathrm{R}^{2}=0.713, \mathrm{~F}=87.239$, sig. $=$ 0.001 .

Source: Author's calculations.

\section{Conclusions, Limitations, and Managerial Implications}

\subsection{Conclusions}

At the outset, we have examined rural customers' perceptions of service quality and satisfaction. The five dimensions' individual mean scores were each greater than 4 , indicating that respondents perceived rural bank service to be of high quality. Respondents attached greatest importance to reliability (mean $=4.81$ ), followed by assurance $(4.79$ ). Responsiveness, with a mean score of 3.39, was ranked fifth. The study has also attempted to identify which dimension has the greatest influence on customer satisfaction. The results of the regression analysis revealed that reliability $(\beta=0.303)$ and assurance $(\beta=0.281)$ were the significant predictors of overall customer satisfaction.

The preliminary analysis suggests that the original 22-item SERVPERF scale fails as a test of universal applicability since it is not unidimensional. Due to poor factor loadings, high cross-loadings, or the creation of subconstructs within their respective latent variables, nine items were dropped at the preliminary analysis stage and further analyses were carried out on 13 items. The psychometric property of the 13-item scale was comparatively better than the original 22-item scale. This finding concurs with that of Adil and Khan (2011), where eight items were dropped and 14 items loaded cleanly onto five dimensions of service quality with better values than the original 22-item SERVPERF scale. 


\subsection{Limitations and Future Research}

The first limitation of this study is that the sample is taken only from a particular region, i.e. Aligarh city, owing to which we should be careful when generalizing the findings. Second, the sample size is 289 , which is very small in contrast to the actual number of patrons resident in rural India. Future researchers need to examine a wider sample covering rural customers from all walks of life. Third, this study has considered the impact of one factor (service quality) on customer satisfaction in rural banks. There may be other situational factors such as advertising, price, repurchase intention, and word-of-mouth recommendation. Subsequent empirical research should look at the impact of these factors on customer satisfaction. Finally, our results relate only to those respondents selected through convenience sampling, hence this study should be seen as a starting point that gives direction for future research and generalization to a wider population of the retail banking industry should be done with some caution.

\subsection{Managerial Implications}

With the advent of privatization and globalization, the banking industry in India is subject to intense competition from banks both within and outside the country. Therefore, banking professionals need to understand how different kinds of customers rate service quality and which critical dimensions contribute to improving it. Since reliability and assurance have emerged as the first and second most important predictors of satisfaction, bank managers should emphasize these dimensions of service quality. Taking their relevant cues, bank managers should emphasize customer-employee interaction in their communication strategies, and provide services at the promised time and the right services the first time. Employees should make customers feel safe when carrying out transactions and take a keen interest in solving their problems. Bank advertisements and other visual materials should emphasize improving the effectiveness of reliability and assurance of service quality in order to enhance the overall satisfaction of rural customers. 


\section{References}

Adil, M. (2011a). Measuring service quality: A comparative study of urban and rural customers of a public bank. In M. Bansal (Ed.), Strategic management of business development: Issues and prospects (pp. 70-73). New Delhi, India: Excel.

Adil, M. (2011b). Assessing service quality at public sector bank: A comparative study of urban and rural customers. International Journal for Business, Strategy and Management, 1(1), 1-9.

Adil, M. (2012). Customer tradeoffs between perceived service quality and satisfaction: A SEM approach towards Indian rural retail banks. In R. Farooqi \& S. W. Ali (Eds.), Emerging paradigms in marketing (pp. 3-16). New Delhi, India: Wisdom Publications.

Adil, M., \& Khan, M. N. (2011). Measuring service quality at rural branches of retail banks: An empirical study. Integral Review: A Journal of Management, 4(1-2), 25-39.

Adil, M., \& Khan, M. N. (2012). Mapping service quality at banks in rural India: Scale refinement and validation. Prabhandgyan: International Journal of Management, 1, 10-20.

Aldlaigan, A. H., \& Buttle, F. A. (2002). SYSTRA-SQ: A new measure of bank service quality. International Journal of Service Industry Management, 13(4), 362-381.

Al-Eisa, A. S., \& Alhemoud, A. M. (2009). Using a multiple-attribute approach for measuring customer satisfaction with retail banking services in Kuwait. International Journal of Bank Marketing, 27(4), 294-314.

Anderson, E. W., \& Mittal, V. (2000). Strengthening the satisfaction-profit chain. Journal of Service Research, 3(2), 107-120.

Angur, M. G., Nataraajan, R., \& Jaheera, J. S., Jr. (1999). Service quality in the banking industry: an assessment in a developing economy. International Journal of Bank Marketing, 13(3), 116-123.

Arasli, H., Turan Katrircioglu, S., \& Mehtap-Smadi, S. (2005). A comparison of service quality in the banking industry: Some evidence from Turkish and Greek speaking areas in Cyprus. International Journal of Bank Marketing, 23(7), 508-526. 
Asubonteng, P., McCleary, K. J., \& Swan, J. E. (1996). SERVQUAL revisited: A critical review of service quality. Journal of Services Marketing, 10(6), 62-81.

Athanassopoulos, A. (2000). Customer satisfaction cues to support market segmentation and explain switching behavior. Journal of Business Research, 47(3), 191-207.

Athanassopoulos, A., Gournaris, S., \& Stathakopoulos, V. (2001). Behavioral responses to customer satisfaction: An empirical study. European Journal of Marketing, 35(5/6), 687-708.

Avkiran, N. K. (1994). Developing an instrument to measure customer service quality in branch banking. International Journal of Bank Marketing, 12(6), 10-18.

Beerli, A., Martin, J. D., \& Quintana, A. (2004). A model of customer loyalty in the retail banking market. European Journal of Marketing, 38(1/2), 253-275.

Bei, L. T., \& Chiao, Y. C. (2006). The determinants of customer loyalty: An analysis of intangible factors in three service industries. International Journal of Commerce and Management, 16(3/4), 162-177.

Bergkvist, L., \& Rossiter, J. R. (2007). The predictive validity of multi-item versus single-item measures of the same constructs. Journal of Marketing Research, 44, 175-184.

Bitner, M. J., Booms, B. H., \& Tetreault, M. S. (1990). The service encounter: Diagnosing favorable and unfavorable incidents. Journal of Marketing, 54(1), 71-84.

Bolton, R. N., \& Drew, J. H. (1988). A model of perceived service value: Technical note (pp. 88-420). Waltham, MA: GTE Laboratories.

Bolton, R. N., \& Drew, J. H. (1991). A multistage model of customers' assessment of service quality and value. Journal of Consumer Research, 54, 69-82.

Boulding, W., Kalra, A., Staelin, R., \& Zeithaml, V. (1993). A dynamic process model of service quality: From expectations to behavioral intentions. Journal of Marketing Research, 30(1), 55-68. 
Brochado, A. (2009). Comparing alternative instruments to measure service quality in higher education. Quality Assurance in Education, 17(2), 174-190.

Caru, A., \& Cugini, A. (1999). Profitability and customer satisfaction in services. International Journal of Service Industry Management, 10(2), 132-157.

Churchill, G. A., Jr., \& Surprenant, C. (1982). An investigation into the determinants of customer satisfaction. Journal of Marketing Research, $19,491-504$.

Coleby, D. E., \& Duffy, A. P. (2005). A visual interpretation rating scale for validation of numerical models. COMPEL: The International Journal for Computation and Mathematics in Electrical and Electronic Engineering, 24(4), 1078-1092.

Cronbach, L. J. (1951). Coefficient alpha and the internal structures of tests. Psychometrika, 16(3), 297-333.

Cronin, J. J., \& Taylor, S. A. (1992). Measuring service quality: A reexamination and extension. Journal of Marketing, 56, 55-68.

Field, A. (2009). Discovering statistics using SPSS (3rd ed.). New Delhi, India: Sage.

Fournier, S. \& Mick, D. G. (1999). Rediscovering satisfaction. Journal of Marketing, 63(4), 5-23.

Hair, J. F., Black, W. C., Babin, B. J., Anderson, R. E., \& Tatham, R. L. (2006). Multivariate data analysis (6 $6^{\text {th }}$ ed.). Upper Saddle River, NJ: Pearson University Press.

Hansen, U., \& Hennig-Thurau, T. (1999). National customer satisfaction indices: A critical investigation from an application perspective. In P. Kunst, J. Lemmink, \& B. Strauss (Eds.), Service quality and management (pp. 25-53). Weisbaden, Germany: Gabler Verlag.

Heskett, J., Sasser, W., \& Schlesinger, L. (1997). The service profit chain. New York, NY: The Free Press. 
Ijaz, A., Irfan, S. M., Shahbaz, S., Awan, M., \& Sabir, M. (2011). An empirical model of student satisfaction: Case of Pakistani public sector business schools. Journal of Quality and Technology Management, 7(2), 91-114.

India, Ministry of Home Affairs. (2011). Census of India: Provisional population totals - Paper 1 of 2011 Series 10 - Uttar Pradesh. New Delhi, India: Author.

Jain, S. K., \& Gupta, G. (2004). Measuring service quality: SERVQUAL vs. SERVPERF scales. Vikalpa, 29(2), 25-37.

Jamal, A., \& Naser, K. (2002). Customer satisfaction and retail banking: An assessment of some of the key antecedents of customer satisfaction in retail banking. International Journal of Bank Marketing, 20(4), 146-160.

Kamath, K. V. (2003). Indian banking sector: Challenges and opportunities. Vikalpa, 28(3), 83-99.

Karatepe, O. M., Yavas, U., \& Babakus, E. (2005). Measuring service quality of banks: Scale development and validation. Journal of Retailing and Consumer Services, 12, 373-383.

Khan, M. N., \& Adil, M. (2011). Critical factors in service delivery: A comparison of urban and rural branches of State Bank of India. International Journal of Management Development and Information Technology, 9(1), 15-23.

Kotler, P., \& Amstrong, G. (2006). Principles of marketing (11 ${ }^{\text {th }}$ ed.). Upper Saddle River, NJ: Pearson-Prentice Hall.

Kumar, S., \& Gulati, R. (2010). Measuring efficiency, effectiveness and performance of Indian public sector banks. International Journal of Productivity and Performance Management, 59(1), 51-74.

Ladhari, R. (2009). Assessment of the psychometric properties of SERVQUAL in the Canadian banking industry. Journal of Financial Services Marketing, 14(1), 70-82.

Levesque, T., \& McDougall, G. (1996). Determinants of customer satisfaction in retail banking. International Journal of Bank Marketing, 14(7), 12-20. 
Mazis, M. B., Ahtola, O. T., \& Klippel, R. E. (1975). A comparison of four multi-attribute models in the prediction of consumer attitudes. Journal of Consumer Research, 2, 38-52.

McGorry, S. Y. (2000). Measurement in a cross-cultural environment: Survey translation issues. Qualitative Market Research: An International Journal, 3(2), 74-81.

McKinsey \& Company. (2010). India banking 2010: Towards a high performing sector. India: Author.

Meng, F., Tepanon, Y., \& Uysal, M. (2008). Measuring tourist satisfaction by attribute and motivation: The case of a nature-based resort. Journal of Vacation Marketing, 14(1), 41-56.

Meuter, M. L., Ostrom, A. L., Roundtree, R. I., \& Bitner, M. J. (2000). Selfservice technologies: Understanding customer satisfaction with technology-based service encounters. Journal of Marketing, 64, 50-64.

Mishra, A. A. (2009). A study on customer satisfaction in Indian retail banking. IUP Journal of Management Research, 8(11), 45-61.

Moutinho, L., \& Goode, M. (1995). The effects of free banking on overall satisfaction: The use of automated teller machines. International Journal of Bank Marketing, 13(4), 33-40.

Muffato, M., \& Panizzolo, R. (1995). A process-based view for customer satisfaction. International Journal of Quality and Reliability Management, 12(9), 154-169.

Narang, R. (2010). Measuring perceived quality of health care services in India. International Journal of Health Care Quality Assurance, 23(2), $171-186$.

Newman, K. (2001). Interrogating SERVQUAL: A critical assessment of service quality measurement in a high street retail bank. International Journal of Bank Marketing, 19(3), 126-139.

Oliver, R. A. (1980). Cognitive model of the antecedents and consequences of satisfaction decisions. Journal of Marketing Research, 17, 460-469. 
Olorunniwo, F., Hsu, M., \& Udo, G. (2006). Service quality, customer satisfaction, and behavioral intentions in the service factory. Journal of Service Marketing, 20(1), 59-73.

Parasuraman, A., Zeithaml, V., \& Berry, L. (1988). SERVQUAL: A multiitem scale for measuring consumer perceptions of SQ. Journal of Retailing, 64(1), 12-40.

Patsiotis, A. G., Hughes, T., \& Webber, D. J. (2012). Adopters and nonadopters of Internet banking: A segmentation study. International Journal of Bank Marketing, 30(1), 20-42.

Pitt, L. F., Watson, R. T., \& Kavan, C. B. (1995). Service quality: A measure of information systems effectiveness. MIS Quarterly, 19(2), 173-188.

Reichheld, F. (1996). The loyalty effect. Cambridge, MA: Harvard Business School Press.

Saunders, M., Thornhill, A., \& Lewis, P. (2000). Research methods for business students ( $2^{\text {nd }}$ ed.). Harlow: Prentice-Hall.

Selvaraj, M. (2009). Total quality management in Indian commercial banks: A comparative study. Journal of Marketing and Communication, 4(3), $59-70$.

Shin, D. \& Elliott, K. (2001). Measuring customers' overall satisfaction: a multi-attributes assessment. Services Marketing Quarterly, 22(1), 3-20.

Smith, A., \& Bolton, R. (2002). The effect of customers' emotional responses to service failures on their recovery effort evaluations and satisfaction judgments. Journal of the Academy of Marketing Science, 30(1), 5-23.

Soderlund, M., \& Ohman, N. (2003). Behavioral intentions in satisfaction research revisited. Journal of Consumer Satisfaction, Dissatisfaction and Complaining Behavior, 16, 53-66.

Spreng, R. A., \& Mackoy, R. D. (1996). An empirical examination of a model of perceived service quality and satisfaction. Journal of Retailing, 72(2), 201-214.

Subbarao, D. (2010). Financial stability report. New Delhi, India: Reserve Bank of India. 
Sureshchandar, G. S., Rajendran, C., \& Anantharaman, R. N. (2002). The relationship between service quality and customer satisfaction: A factor specific approach. Journal of Services Marketing, 16(4), 363-379.

Sureshchandar, G. S., Rajendran, C., \& Anantharaman, R. N. (2003). Customer perceptions of service quality in the banking sector of a developing economy: A critical analysis. International Journal of Bank Marketing, 21(5), 233-242.

Taylor, S. A., \& Baker, T. L. (1994). An assessment of the relationship between service quality and customer satisfaction in the formation of consumers' purchase intentions. Journal of Retailing, 70(2), 163-178.

Trochim, W. M. (2006). The research methods knowledge base. Retrieved April 20, 2012 from http:/ / www.socialresearchmethods.net/kb/

Vanniarajan, T., \& Anbazhagan, B. (2007). SERVPERF analysis in retail banking. Proceedings of the International Marketing Conference on Marketing and Society, Part VII, Regulations and Marketing, 725-736.

Vanniarajan, T., \& Nainamohamed, K. (2008). Mapping service quality in the Indian banking industry. Journal of Marketing and Communication, 4(1), 23-36.

Walker, A., Smither, J., \& Waldman, D. (2008). A longitudinal examination of concomitant changes in team leadership and customer satisfaction. Personnel Psychology, 61(3), 547-577.

Wood, J. (2008). The effect of buyers' perceptions of environmental uncertainty of satisfaction and loyalty. Journal of Marketing Theory and Practice, 16(4), 309-320.

Woodruff, R. B., Cadotte, E. R., \& Jenkins, R. L. (1983). Modeling consumer satisfaction processes using experience-based norms. Journal of Marketing Research, 20, 296-304.

Yavas, U., Bilgin, Z., \& Shemwell, D. J. (1997). Service quality in the banking sector in an emerging economy: A consumer survey. International Journal of Bank Marketing, 15(6), 217-223.

Zeithaml, V. A. (1998). Consumer perceptions of price, quality, and value: A means-end model and synthesis of evidence. Journal of Marketing, $52,2-22$. 
